\title{
Extraction, antioxidative, and antimicrobial activities of brown seaweed extracts, Turbinaria ornata and Sargassum polycystum, grown in Thailand
}

\author{
Saowapa Rattaya $\cdot$ Soottawat Benjakul $\cdot$ \\ Thummanoon Prodpran
}

Received: 20 July 2014/ Accepted: 24 October 2014/Published online: 13 November 2014

(C) The Author(s) 2014. This article is published with open access at Springerlink.com

\begin{abstract}
Total phenolic content and antioxidative and antimicrobial activities of methanolic and ethanolic extracts from brown seaweeds, Turbinaria ornata and Sargassum polycystum, were determined. Among all extracts, methanolic extract of $T$. ornata contained the highest total phenolic content $(2.07 \mathrm{mg}$ catechin $/ \mathrm{g}$ dry seaweed) $(p<0.05)$ and exhibited the highest antioxidative activity as indicated by the greatest ABTS and DPPH radical scavenging activity as well as reducing activity power (RAP), compared with other extracts $(p<0.05)$. When different concentrations of seaweed extracts $(100-500 \mathrm{mg} / \mathrm{L})$ were used, antioxidative activities were dose-dependent. Correlations between ABTS and DPPH radical scavenging activity; DPPH radical scavenging activity and RAP; ABTS radical scavenging activity and RAP were observed. Therefore, antioxidants in seaweed extracts possessed the capability of scavenging the radicals together with reducing power. The efficacy in prevention of lipid oxidation of methanolic extract of $T$. ornata in lecithin-liposome and linoleic oxidation systems was studied. The extract at levels of $100-500 \mathrm{mg} / \mathrm{L}$ could retard the oxidation, regardless of chlorophyll removal but its efficacy was lower than that of BHT at levels of 50 and $200 \mathrm{mg} / \mathrm{L}$. For antimicrobial activity, all extracts could not inhibit the growth of Bacillus subtilis, Salmonella enteritidis, and Aspergillus niger, while Staphylococcus aureus was inhibited with the extracts at $500 \mathrm{mg} / \mathrm{L}$.
\end{abstract}

Keywords Seaweed extract - Antioxidant activity $\cdot$ DPPH $\cdot$ ABTS $\cdot$ RAP $\cdot$ Lipid oxidation $\cdot$ Antimicrobial activity

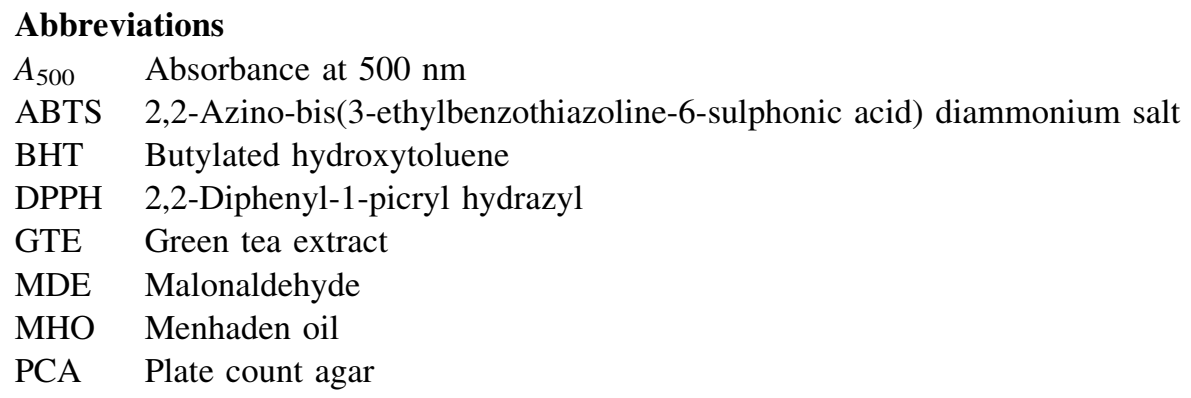

S. Rattaya $\cdot$ S. Benjakul

Department of Food Technology, Faculty of Agro-Industry, Prince of Songkla University, 15 Kanchanawanish Road, Hat Yai, Songkhla 90112, Thailand

T. Prodpran $(\triangle)$

Department of Material Product Technology, Faculty of Agro-Industry, Prince of Songkla University, 15 Kanchanawanish Road, Hat Yai, Songkhla 90112, Thailand

e-mail: thummanoon.p@psu.ac.th 


$\begin{array}{ll}\text { RAP } & \text { Reducing activity power } \\ \text { SBO } & \text { Seal blubber oil } \\ \text { TCC } & \text { Total chlorophyll content } \\ \text { TEAC } & \text { Trolox equivalent antioxidant capacity } \\ \text { TPC } & \text { Total phenolic contents }\end{array}$

\section{Introduction}

Lipid oxidation and microbial spoilage are the major deteriorative processes in foods, leading to unacceptability for the consumers and a loss in nutritional value. Additionally, oxidation leads to health disorders such as altherosclerosis and cancerogenesis (Kehrer 1993; Kranl et al. 2005). Hence, the antioxidants and antimicrobial agents have been widely used to maintain the quality, acceptability, and safety of foods (Koleva et al. 2003). Nevertheless, synthetic antioxidant and antimicrobial agents in food products are under strict regulation due to the potential health hazards (Kranl et al. 2005). Therefore, the search for natural antioxidants and antimicrobial as alternatives to synthetic counterpart is of great interest.

Seaweeds or marine macroalgae are potential renewable resources in the marine environment. About 6000 species of seaweeds have been identified and are grouped into different classes including green (Chlorophytes), brown (Pheophytes), and red (Rhodophytes) algae (Abbott 1995). Seaweeds have been widely used for the production of hydrocolloids such as agar, carrageenan. and alginates. Additionally, marine algae extracts were demonstrated to have strong antioxidant properties (Kuda et al. 2005), protective effects against liver injury caused by carbon tetrachloride, antimicrobial activity and antiviral properties (Newman et al. 2003). However, algae grown in Thailand are still underutilized. Only small portion has been used as food, animal fodder, fertilizers, and for the production of hydrocolloids (Aungtonya and Liao 2002).

In recent years, many marine algae extracts have been demonstrated to have antioxidant (Kuda et al. 2005) as well as antimicrobial properties (Ely et al. 2004). Seaweeds are considered to be a rich source of antioxidants (Cahyana et al. 1992). The potential antioxidant compounds were identified as some pigments (e.g., fucoxanthin, astaxanthin, carotenoid) and polyphenols (e.g., phenolic acid, flavonoid, tannins) (Yoshie et al. 2000). Those compounds are widely distributed in plants or seaweeds and are known to exhibit antioxidative activities via reactive oxygen species scavenging activity and the inhibition of lipid per-oxidation (Athukorala et al. 2003; Heo et al. 2005; Siriwardhana et al. 2003). Plant extracts have been reported to possess antimicrobial activity, mainly from phenolic compounds or essential oil. The extracts from seaweed have been reported to exhibit the antimicrobial activity and can be used as natural antimicrobial agent (Bennamara et al. 1999; Ely et al. 2004). Moreover, chlorophylls in plants have been also reported to have pro-oxidant activity, providing protection of vegetable edible oils by preventing autoxidation (Wanasundara and Shahidi 1998)

However, there exist few reports on the antioxidant and antimicrobial activities of seaweeds from southern coast of Thailand. To maximize the utilization of seaweeds, particularly brown seaweeds which are common in southern Thailand, the uses of their extracts as natural antioxidant and antimicrobial should be focused. The brown algae, being in the division of Pheophyta, are brownish in color due to the large amounts of the caroteniod fucoxanthin masking the remaining pigments, chlorophyll $a$ and $c, \beta$-carotene, and other xanthophylls. Cell walls are composed of alginic acid which can be extracted as algin or alginate, used for various industrial purposes. The brown algae range in size from small filaments to the largest marine algae. Most members of this division are almost exclusively of marine occurrence. Most of the brown algae grow in the intertidal belt and the upper littoral region (Abbott 1995). Two brown algae, Sargassum polycystum and Turbinaria ornata, which are common in southern part of Thailand (Lewmanomont 1995) were focused in this present study.

Sargassum polycystum (Fig. 1a) proliferates in tropical waters. In Thailand, it is found in Gulf of Thailand and Andaman Sea. In Chumporn Province, it has been used as food, fertilizer for palm tree (Lewmanomont 1995; Yangthong et al. 2009). T. ornata (Fig. 1b) is widely distributed from the Indo-Pacific through the Caribbean (Ang, 1986). T. ornata has invaded large areas on the intertidal and shallow sub-tidal shores in French Polynesia and Hawaii (Smith et al. 2002). It is also common and abundant on the shore at Samui Island 

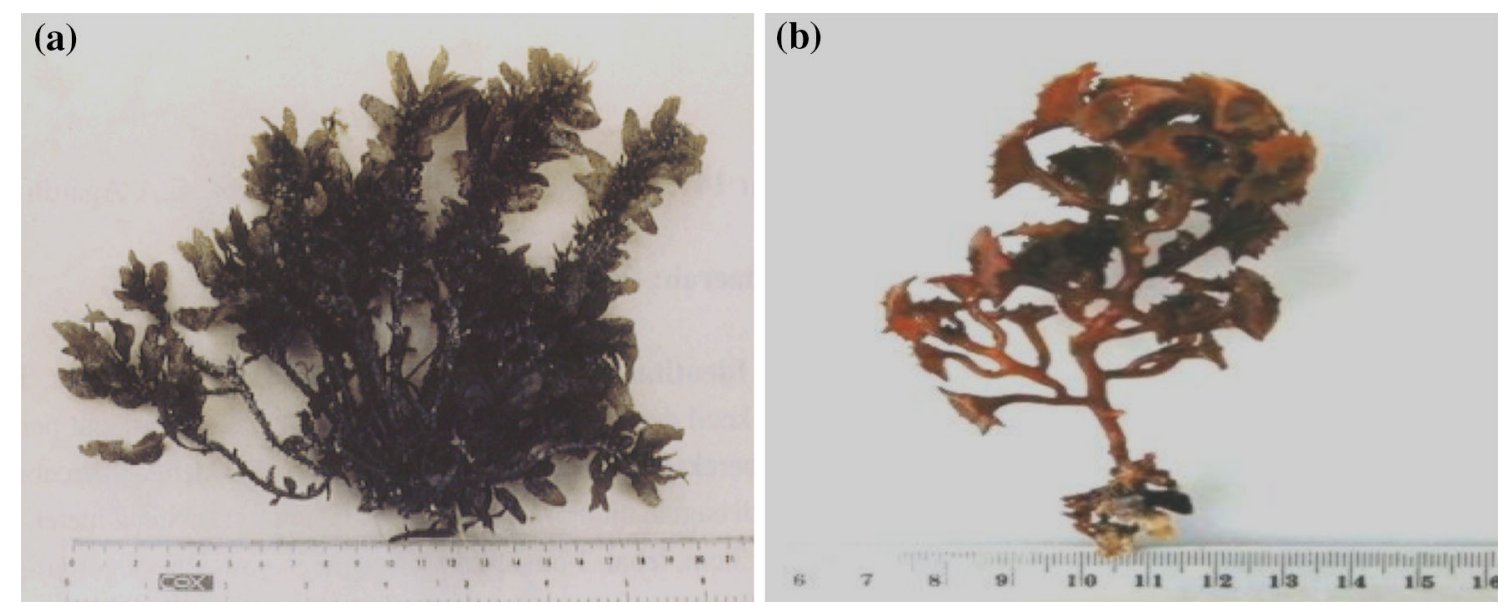

Fig. 1 Sargassum polycystum (a) and Turbinaria ornata (b) (Lewmanomont 1995)

(Mayakun and Prathep 2005) and Koh Pling, Sirinart Marine National Park, Phuket Island, Southern Thailand (Prathep 2005), where it occurs over a wide range from sheltered to very exposed shores and from the intertidal to shallow sub-tidal zones.

Therefore, in this present study, chemical property as well as antioxidant activity in various systems and antimicrobial activity of brown algae including $S$. polycystum and $T$. ornata were investigated. The knowledge of their antioxidant and antimicrobial activities could potentially elevate their beneficial value as food and additives, and expand their dietary market.

\section{Materials and methods}

Materials, chemicals, and enzyme

\section{Collection and preparation of seaweed}

Brown seaweeds, T. ornata and S. polycystum, were collected freshly from Samui Island, Suradthanee Province, Thailand. Samples collected were washed thoroughly with tap water, packed in polyethylene bag and transported to the Department of Material Product Technology, Prince of Songkla University, Hat Yai within $5 \mathrm{~h}$. Upon arrival, seaweeds were dried at $35^{\circ} \mathrm{C}$ for $24 \mathrm{~h}$ using an air-force oven. The dried seaweeds were powdered using a blender (National, MX-T2GN, Taipei, Taiwan). Then powder was sieved using a screen with a diameter of $0.5 \mathrm{~mm}$. The seaweed powder was placed in the polyethylene bag and stored at $4{ }^{\circ} \mathrm{C}$ until use.

\section{Chemicals and enzyme}

Sodium chloride $(\mathrm{NaCl})$, urea, and sodium dodecylsulfate (SDS) were purchased from Univar (Worksafe, Australia). Glycerol, $\alpha$-chymotrypsin, and Coomassie Brilliant Blue G250 were purchased from Wako Pure Chemical Industry, Ltd. (Tokyo, Japan). Methanol was obtained from Merk (Darmstadt, Germany). 2,2-Azino-bis(3-ethylbenzothiazoline-6-sulfonic acid) diammonium salt (ABTS), 6-hydroxy-2,5,7,8-tetramethylchroman-2-carboxylic acid (Trolox), 2,2-diphenyl-1-picryl hydrazyl (DPPH), linoleic acid, $\beta$ mercaptoethanol $(\beta$-ME), and L- $\alpha$-phosphatidylcholine (L- $\alpha$-lecithin) were purchased from Sigma Chemical Co. (St. Louis, MO, USA). Acrylamide, $N, N, N^{\prime} N^{\prime}$ - tetramethylethylenediamine (TEMED), 2-thiobarbituric acid, bis-acrylamide, Ferric chloride hexahydrate, 2-thiobarbituric acid, butylated hydroxytoluene (BHT), and potassium persulfate were procured from Fluka Chemical Co. (Buchs, Switzerland). 
Extraction and characterization of seaweed extracts

Preparation of seaweed extracts

Seaweed powder $(5 \mathrm{~g})$ was mixed with $150 \mathrm{ml}$ of solvents, either methanol or ethanol following the method of Terada et al. (1987). The mixtures were homogenized at $10,000 \times g$ for 2 min using IKA LABOTECHNIK homogenizer (model T25 basic, ULTRA TURREX ${ }^{\circledR}$, Selangor Malaysia). The homogenate was then stirred continuously at room temperature for $30 \mathrm{~min}$. The mixtures were centrifuged at 5,000 $\times \mathrm{g}$ for $10 \mathrm{~min}$ at room temperature using a Sorvall Model RC-5B Plus refrigerated centrifuge (Newtown, CT, USA) to remove undissolved debris. A portion of extract was subjected to chlorophyll removal as per the method of LanferMarquez et al. (2005). The extract was mixed with petroleum ether at a ratio of 5:2(v/v) at room temperature. The extraction was repeated for 3 times. The layer of petroleum ether was drawn off. The solvent in the extracts without and with chlorophyll removal was removed by a rotary evaporator (Model Rotavapor-R, Brinkmann, Switzerland) at $40{ }^{\circ} \mathrm{C}$. The volume of evaporated extract was adjusted to $10 \mathrm{ml}$ using the same solvent.

\section{Chlorophyll content determination}

Total chlorophyll content was determined spectrophotometrically according to the method of the AOAC (2000). Methanolic and ethanolic extracts of seaweed with and without chlorophyll removal prepared as previously described were dehydrated with anhydrous sodium sulfate. Immediately, the pigments were quantified spectrophotometrically at 660 and $642.50 \mathrm{~nm}$. For the blank, methanol or ethanol was used instead of extracts. Total chlorophyll content (TCC) was calculated using the following equation:

$$
\mathrm{TCC}(\mathrm{mg} / \mathrm{g} \text { dry extract })=7.12\left(A_{660}\right)+16.8\left(A_{642}\right) .
$$

\section{Total phenolic content determination}

Total phenolic content was determined with Folin-Ciocalteu reagent according to the method of Slinkard and Singleton (1997). One $\mathrm{ml}$ of seaweed extract was added with $200 \mu \mathrm{l}$ of reagent (the mixture of FolinCiocalteu reagent and deionized water, $1: 1(\mathrm{v} / \mathrm{v}))$ and mixed thoroughly. After $3 \mathrm{~min}, 3 \mathrm{ml}$ of $2 \% \mathrm{Na}_{2} \mathrm{CO}_{3}$ was added. The mixture was allowed to stand at room temperature for $30 \mathrm{~min}$. The absorbance was measured at $760 \mathrm{~nm}$ using a UV-16001 spectrophotometer (Shimadzu, Kyoto, Japan). The concentration of total phenolic compounds in seaweed extract was calculated from the standard curve of catechin with the range of $0.01-0.1 \mathrm{mg} / \mathrm{ml}$ and expressed as $\mathrm{mg}$ catechin/g dry seaweed.

Study on antioxidative activity of seaweed extracts

Ethanol and methanol extract from both seaweeds without and with chlorophyll removal were subjected to determination of antioxidative activity.

\section{DPPH radical scavenging activity}

DPPH radical scavenging activity was determined as described by Wu et al. (2003) with a slight modification. Sample $(1.5 \mathrm{ml})$ was added with $1.5 \mathrm{ml}$ of $0.15 \mathrm{mM}$ DPPH in $95 \%$ methanol. The mixture was then mixed vigorously and allowed to stand at room temperature in dark for $30 \mathrm{~min}$. The absorbance of resulting solution was measured at $517 \mathrm{~nm}$ using an UV-1601 spectrophotometer (Shimadzu, Kyoto, Japan). The control was prepared in the same manner except that the distilled water was used instead of sample. The sample blank was prepared by using ethanol or methanol instead of DPPH solution. The standard curve was prepared using Trolox in the range of $10-60 \mu \mathrm{M}$. The activity was expressed as $\mu \mathrm{mol}$ Trolox equivalents (TE) $/ \mathrm{ml}$. 
ABTS radical scavenging activity

ABTS radical scavenging activity was determined as per the method of Arnao et al. (2001) with a slight modification. The stock solutions included 7.4 mM ABTS solution and $2.6 \mathrm{mM}$ potassium persulfate solution. The working solution was prepared by mixing the two stock solutions in equal quantities and allowing them to react for $12 \mathrm{~h}$ at room temperature in dark. The solution was then diluted by mixing $1 \mathrm{ml}$ of ABTS solution with $30 \mathrm{ml}$ of methanol to obtain an absorbance of $1.1 \pm 0.02$ at $734 \mathrm{~nm}$ using an UV-1601 spectrophotometer (Shimadzu, Kyoto, Japan). ABTS solution was freshly prepared for each assay. Sample (150 $\mu$ l) was mixed with $2.85 \mathrm{ml}$ of ABTS solution, and the mixture was left at room temperature for $2 \mathrm{~h}$ in dark. The sample blank was prepared by using methanol instead of ABTS solution. The absorbance was then measured at $734 \mathrm{~nm}$ using the spectrophotometer. The standard curve of Trolox ranging from 50 to $600 \mu \mathrm{M}$ was prepared. The activity was expressed as $\mu$ mol Trolox equivalent (TE)/ml.

\section{Reducing power}

Reducing power was determined according to the method of $\mathrm{Wu}$ et al. (2003) with a slight modification. Diluted sample $(1 \mathrm{ml})$ was mixed with $1 \mathrm{ml}$ of $0.2 \mathrm{M}$ phosphate buffer (pH 6.6) and $1 \mathrm{ml}$ of $1 \%$ potassium ferricyanide. The mixtures were incubated at $50{ }^{\circ} \mathrm{C}$ for $20 \mathrm{~min}$, followed by addition of $1 \mathrm{ml}$ of $10 \%$ trichloroacetic acid. An aliquot $(1 \mathrm{ml})$ of reaction mixture was added with $1 \mathrm{ml}$ of distilled water and $200 \mu \mathrm{l}$ of $0.1 \% \mathrm{FeCl}_{3}$. The absorbance of resulting solution was measured at $700 \mathrm{~nm}$. Increased absorbance of the reaction mixture indicates the increased reducing power. The sample blank was prepared by using methanol instead of $\mathrm{FeCl}_{3}$ solution.

\section{Determination of antioxidative activity of seaweed extract in different systems}

Methanolic extracts of $T$. ornata with and without chlorophyll removal at different concentrations were tested in different systems. BHT at levels of 50 and $200 \mathrm{mg} / \mathrm{L}$ was used for comparison purpose. For the control, methanol was added instead of the extract or BHT.

\section{Lecithin liposome system}

Antioxidative activity of seaweed extracts in lecithin liposome system was determined according to the method of Frankel et al. (1996). Lecithin was suspended in deionized water at a concentration of $8 \mathrm{mg} / \mathrm{ml}$. The mixture was stirred with glass rod, followed by sonicating for $30 \mathrm{~min}$ using a sonicating bath (Transsonic 460/H, Elma, Germany). Seaweed extracts were mixed with lecithin liposome to obtain the final concentrations of 100, 200, and $500 \mathrm{mg} / \mathrm{L}$. The liposome suspension was then sonicated for $2 \mathrm{~min}$. To initiate the assay, $20 \mu \mathrm{l}$ of $0.15 \mathrm{M}$ cupric acetate was added. The mixture was shaken at $120 \mathrm{rpm}$ using a shaker (UNIMAX 1010, Heidolph, Germany) at $37{ }^{\circ} \mathrm{C}$ in dark for $0,6,12,18,24,30,42$, and 48 h. Liposome oxidation was monitored by determining thiobarbituric acid-reactive substances (TBARS). TBARS values were calculated from the standard curve of (0-3 mg/L malonaldehyde (MDA)) and expressed as mg MDA/ml liposome.

\section{Linoleic oxidation system}

Antioxidative activity of seaweed extracts in linoleic oxidation system was tested as described by Sakanaka et al. (2004). Seaweed extracts were mixed with $10 \mathrm{ml}$ of $50 \mathrm{mM}$ linoleic acid in $99.5 \%$ ethanol to obtain the final concentrations of 100, 200, and $500 \mathrm{mg} / \mathrm{l}$ and the mixture was kept at $40{ }^{\circ} \mathrm{C}$ in dark. During incubation, aliquots of the reaction mixtures were taken for measurement of the oxidation using the ferric thiocyanate method every day for totally 10 days. To $50 \mu \mathrm{l}$ of the reaction mixture, $2.35 \mathrm{ml}$ of $75 \%$ ethanol, $50 \mu \mathrm{l}$ of $30 \%$ ammonium thiocyanate, and $50 \mu \mathrm{l}$ of $20 \mathrm{mmol} / \mathrm{L}$ ferrous chloride solution in $3.5 \% \mathrm{HCl}$ were added and mixed thoroughly. After $3 \mathrm{~min}$, the absorbance of the colored solution was measured at $500 \mathrm{~nm}$. For the control, methanol was added instead of antioxidant in the assay system. BHT at level of 50 and $200 \mathrm{mg} / \mathrm{L} \mathrm{was}$ also used. 
Study on antimicrobial activity of seaweed extracts

\section{Microorganisms}

Bacillus subtilis, Staphylococcus aureus, Salmonella enteritidis, and Aspergillus niger were obtained from the Department of Microbiology, Prince of Songkla University, Hat Yai, Thailand. The microorganisms were subcultured in slant plate count agar for B. subtilis, S. aureus, and S. enteritidis and potato dextrose agar (PDA) for A. niger and kept at $4{ }^{\circ} \mathrm{C}$ until use.

\section{Determination of antimicrobial activity of seaweed extracts}

Antimicrobial activity was tested according to the method of Baydar et al. (2005). The microorganism subcultured in slant (1 loop) was incubated in tubes of nutrient broth $(10 \mathrm{ml})$ at $37{ }^{\circ} \mathrm{C}$ for $18-24 \mathrm{~h}$ to obtain approximately $10^{7}-10^{8}$ colony forming units $/ \mathrm{ml}(\mathrm{CFU} / \mathrm{ml})$. The solutions $(0.1 \mathrm{ml})$ were spread on plate count agar (PCA) for B. subtilis, S. aureus, and S. enteritidis and potato dextrose agar (PDA) for A. niger. Sterile disks $(5 \mathrm{~mm})$ prepared from Whatman No. 4 filter paper were absorbed with $50 \mu \mathrm{l}$ of either methanolic or ethanolic seaweed extract at different concentrations $(0,100,200,300,400$, and $500 \mathrm{mg} / \mathrm{L})$. The disks were dried at $40{ }^{\circ} \mathrm{C}$ for $30 \mathrm{~min}$ and placed onto surface of each microorganism plate and incubated at $37{ }^{\circ} \mathrm{C}$ for $24 \mathrm{~h}$. The inhibition zones were measured as the diameter of disk.

Statistical analysis

All experiments were run in triplicate. All data were subjected to Analysis of Variance (ANOVA), and the differences between means were evaluated by Duncan's Multiple Range Test. SPSS statistic program (SPSS 11.0 for window, SPSS Inc., Chicago, IL, USA.) was used for data analysis.

\section{Results and discussion}

Extraction and chemical properties of seaweed extracts

\section{Total phenolic content and total chlorophyll content of brown seaweed extracts}

Total phenolic contents (TPC) of methanolic and ethanolic extracts of T. ornata and S. polycystum are presented in Table 1. Without chlorophyll removal, both methanolic and ethanolic of T. ornata contained higher TPC than those of S. polycystum. For the same seaweeds, methanolic extract had the greater TPC than did ethanolic counterpart. Various phenolic compounds including quercetin, myricetin (flavonoles); genistin, daidzein (iso-flavones); hesperidin (flavanones), and lutein (flavones) were found in methanolic extract of red, brown, and green seaweeds (Yoshie et al. 2000; Yangthong et al. 2009; Santoso et al. 2004).

After chlorophyll removal, TPC of the same extract decreased, except for methanolic extract of S. polycystum, in which chlorophyll removal had no impact on TPC. During extraction of chlorophylls using petroleum ether, some phenolics, particularly non-polar, could be removed together with chlorophyll, leading to the lower TPC remained in the extract. Yan et al. (1999) reported some active compounds from brown seaweed, which were identified as phylopheophytin in Eisenia bicyclis and fucoxantine in Hizikia fusiformis. Methanol has been intensively used to extract plant phenols, and its extraction efficiency was generally higher than ethanol (Kumaron and Karunakaran 2007). Lim et al. (2002) reported that phenolic compound of methanolic extract from Sargassum siliquastrum had higher than did ethyl acetate, chloromethane, and buthanol.

Total chlorophyll content (TCC) of different seaweed extracts is shown in Table 2. After chlorophyll removal, methanolic and ethanolic extracts had lower TCC $(p<0.05)$. Since chlorophyll contains several non-polar moieties, it can be extracted out by petroleum ether upon chlorophyll removal (Lanfer-Marquez et al. 2005; Wong 1989). Efficacy in chlorophyll removal varied with seaweeds and solvents used. This was possibly due to different polarities of the solvents used to prepare the extracts which could result in different 
Table 1 Total phenolic content (TPC) of methanolic and ethanolic extract of T. ornata and S. polycystum without and after chlorophyll removal

\begin{tabular}{llc}
\hline Extracts & \multicolumn{2}{l}{ Total phenolic content* ${ }^{*}$ mg catechin/g dry seaweed) } \\
\cline { 3 - 3 } & T. ornata & S. polycystum \\
\hline Methanolic & $2.07 \pm 0.06^{\mathrm{bA} * *}$ & $0.54 \pm 0.09^{\mathrm{aB}}$ \\
After chlorophyll removal & $2.18 \pm 0.01^{\mathrm{aA}}$ & $0.59 \pm 0.01^{\mathrm{aB}}$ \\
Without chlorophyll removal & & $0.22 \pm 0.01^{\mathrm{cB}}$ \\
Ethanolic & $1.03 \pm 0.04^{\mathrm{dA}}$ & $0.32 \pm 0.00^{\mathrm{bB}}$ \\
After chlorophyll removal & $1.25 \pm 0.01^{\mathrm{cA}}$ & \\
Without chlorophyll removal &
\end{tabular}

$*$ Mean $\pm \operatorname{SD}(n=3)$

** Different letters within the same column indicate significant differences $(p<0.05)$ and different capital letters within the same row indicate significant differences $(p<0.05)$

Table 2 Total chlorophyll content of methanolic and ethanolic extract of T. ornata and S. polycystum without and after chlorophyll removal

\begin{tabular}{lll}
\hline Extracts & \multicolumn{2}{l}{ Total chlorophyll content* $(\mu \mathrm{g}$ chlorophyll/g dry seaweed $)$} \\
\cline { 3 - 3 } & T. ornata & S. polycystum \\
\hline Methanolic & & $13.26 \pm 0.10^{\mathrm{dB}}$ \\
After chlorophyll removal & $20.79 \pm 0.29^{\mathrm{dA} * *}$ & $32.09 \pm 0.15^{\mathrm{bA}}$ \\
Without chlorophyll removal & $35.23 \pm 0.04^{\mathrm{bA}}$ & $21.57 \pm 0.05^{\mathrm{cA}}$ \\
Ethanolic & & $37.18 \pm 0.09^{\mathrm{aA}}$ \\
After chlorophyll removal & $25.14 \pm 0.27^{\mathrm{cA}}$ & $37.77 \pm 0.44^{\mathrm{aA}}$ \\
Without chlorophyll removal &
\end{tabular}

* Mean $\pm \operatorname{SD}(n=3)$

** Different letters within the same column indicate significant differences $(p<0.05)$ and different capital letters within the same row indicate significant differences $(p<0.05)$

partitioning abilities of petroleum ether used to remove the chlorophyll and thus leading to different chlorophyll extraction efficiencies. In addition, chlorophyll constituted in various seaweeds might be in different forms so that the extraction efficacy could be varied (Wong 1989). Methanolic extract of S. polycystum had the decrease in TCC by $41.32 \%$ after chlorophyll removal.

Antioxidative activities of brown seaweed extracts

\section{DPPH radical scavenging activity}

DPPH radical scavenging activity of methanolic and ethanolic extracts from T. ornata and S. polycystum without and with chlorophyll removal at different concentrations is shown in Fig. 2. For extract without chlorophyll removal, methanolic extract of $T$. ornata and ethanolic extract of $S$. polycystum exhibited the highest DPPH radical scavenging activity. At the same concentration tested, methanolic extract of $S$. polycystum had the lowest activity. Due to the different TPC between methanolic extract of T. ornata and ethanolic extract of S. polycystum (Table 1), it was suggested that TPC was not correlated well with DPPH radical scavenging activity. It was also presumed that different types of phenolic compounds with different antioxidant activities were presented in both extracts. Polyphenolic constituent in seaweed was capable of functioning as free radical scavengers (Chew et al. 2008). Polyphenols such as phlorotannins, which are bi-polar in nature, were found in brown seaweeds (Burtin 2003). For each extract used, DPPH radical scavenging activity increased with increasing concentration $(p<0.05)$. DPPH is one of the compounds that have a proton-free 
Fig. 2 DPPH radical scavenging activity ( $\mu \mathrm{mol} \mathrm{TE} / \mathrm{ml})$ of methanolic (ME) and ethanolic (EE) extracts of T. ornata and $S$. polycystum without (a) and with (b) chlorophyll removal at various concentrations. Bars represent the standard deviation from triplicate determinations
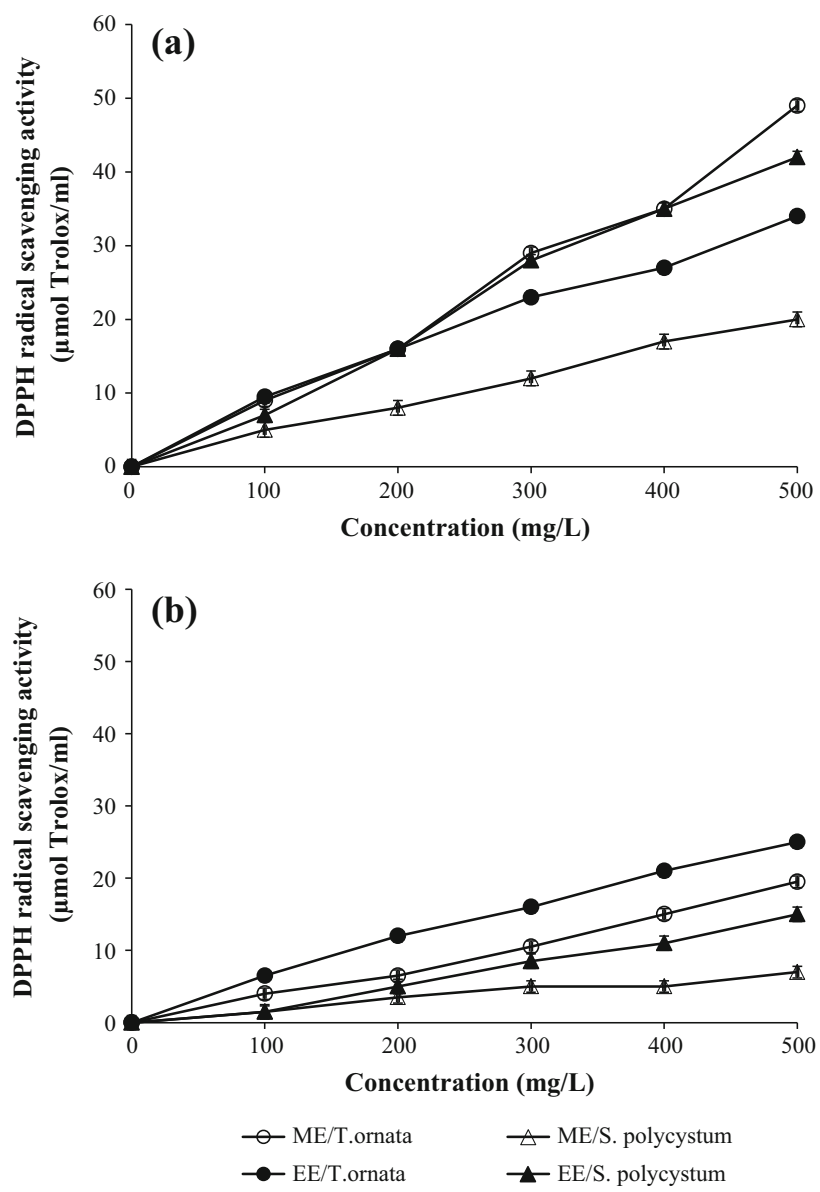

radical with a characteristic absorption, which decreases significantly on exposure to proton radical scavengers (Yamaguchi et al. 1998). It is well accepted that the DPPH radical scavenging by antioxidants is attributable to their hydrogen-donating ability (Chen and Ho 1995). The reduction capability of DPPH radicals was determined by the decrease in its absorbance at $517 \mathrm{~nm}$ induced by antioxidant (GülGin et al. 2004). Therefore, DPPH radical scavenging activity varied with seaweed species. Methanolic extract of three Indian brown seaweeds (Turbinaria conoides, Padina tetrastomatica, and Sargassum marginatum) had different DPPH radical scavenging activities. $T$. conoides extracts showed higher activity than those of $P$. tetrastomatica and $S$. marginatum (Chandini et al. 2008).

After chlorophyll removal, all extracts exhibited the lower DPPH radical activity. Nevertheless, the activity increased as the concentration used increased $(p<0.05)$. With chlorophyll removal, methanolic extract of $T$. ornata had the highest DPPH radical scavenging activity, whereas methanolic extract of $S$. polycystum exhibited the lowest activity at all concentrations tested $(p<0.05)$. The result suggested that chlorophylls contributed to antioxidative activity of seaweed extracts. Endo et al. (1985) reported antioxidative activity of chlorophyll-a, followed by chlorophyll-b and pheophytin. Additionally, chlorophyll removal using petroleum ether might remove some antioxidative compounds from the extracts. As a result, antioxidative compounds in the extracts could be affected by chlorophyll removal process.

\section{ABTS radical scavenging activity}

Methanolic and ethanolic extracts of T. ornata and S. polycystum without and with chlorophyll removal at different concentrations showed different ABTS radical scavenging activities (Fig. 3). ABTS radical scavenging activity of all extracts increased with increasing concentrations $(p<0.05)$. For the extracts without chlorophyll removal (Fig. 3a), methanolic extract of T. ornata exhibited the highest activity $(p<0.05)$, 
Fig. 3 ABTS radical scavenging activity ( $\mu \mathrm{mol} \mathrm{TE} / \mathrm{ml})$ of methanolic (ME) and ethanolic (EE) extracts of $T$. ornata and $S$. polycystum without (a) and with (b) chlorophyll removal at various concentrations. Bars represent the standard deviation from triplicate determinations
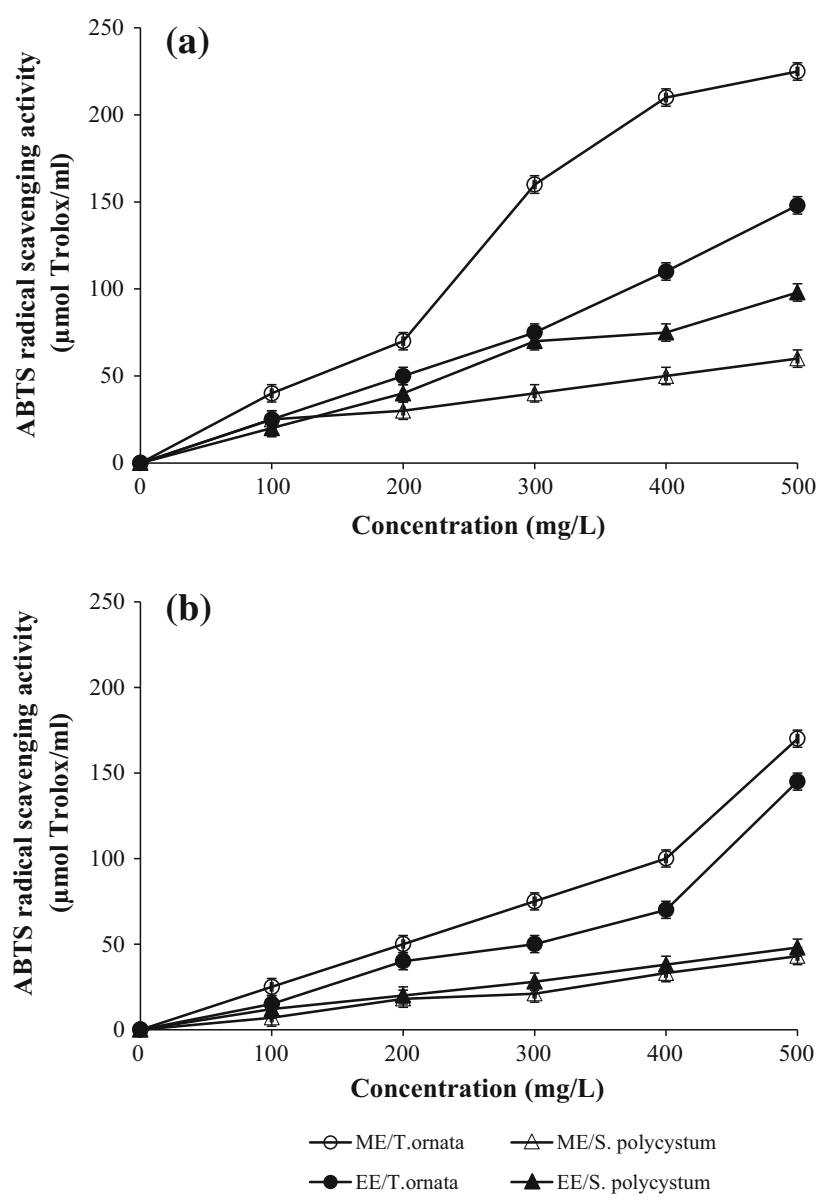

whereas methanolic extract of $S$. polycystum showed the lowest activity $(p<0.05)$. For the extract of $T$. ornata, methanolic extract had the higher ABTS radical scavenging activity than did ethanolic counterpart. Nevertheless, ethanolic extract of $S$. polycystum showed the higher activity than did methanolic counterpart $(p<0.05)$. Different results between DPPH and ABTS radical scavenging activities indicated the differences in mode of action of antioxidants, particularly in term of specificity in radical scavenging. Both of seaweed extracts without chlorophyll removal had higher ABTS radical scavenging activity than did those with chlorophyll removal, indicating that some antioxidative compounds could be removed by petroleum ether used in chlorophyll removing process. Furthermore, removal of chlorophylls, which had antioxidative activity, resulted in the lower activity. Hagerman et al. (1998) reported that molecular weight, the number of aromatic rings, and nature of hydroxyls groups substitution, rather than the specific functional groups, determine antioxidative activity of phenolic compounds. ABTS assay is an excellent tool for determining the antioxidant activity of hydrogen-donating antioxidants (scavengers of aqueous phase radicals) and of chain breaking antioxidants (scavenger of lipid peroxyl radical) (Leong and Shui 2002). For the extracts with chlorophyll removal, ethanolic extract of $T$. ornata had lower ABTS radical scavenging activity than did methanolic counterpart $(p<0.05)$ (Fig. 3b). No differences were noticeable between methanolic and ethanolic extracts of S. polycystum. This reconfirmed that chlorophyll removal affected the types of antioxidative compounds and composition of extracts.

\section{Reducing activity power}

Among all extracts without chlorophyll removal, methanolic extract of $T$. ornata had the highest reducing activity power (RAP) and ethanolic extract of $S$. polycystum showed the lowest RAP $(p<0.05)$ (Fig. 4). After chlorophyll removal, slight decrease in RAP was generally found. In general, extracts from $T$. ornta possessed 
Fig. 4 Reducing activity power $(\mu \mathrm{mol} \mathrm{TE} / \mathrm{ml})$ of methanolic (ME) and ethanolic (EE) extracts of $T$. ornata and $S$. polycystum without (a) and with (b) chlorophyll removal at various concentrations. Bars represent the standard deviation from triplicate determinations
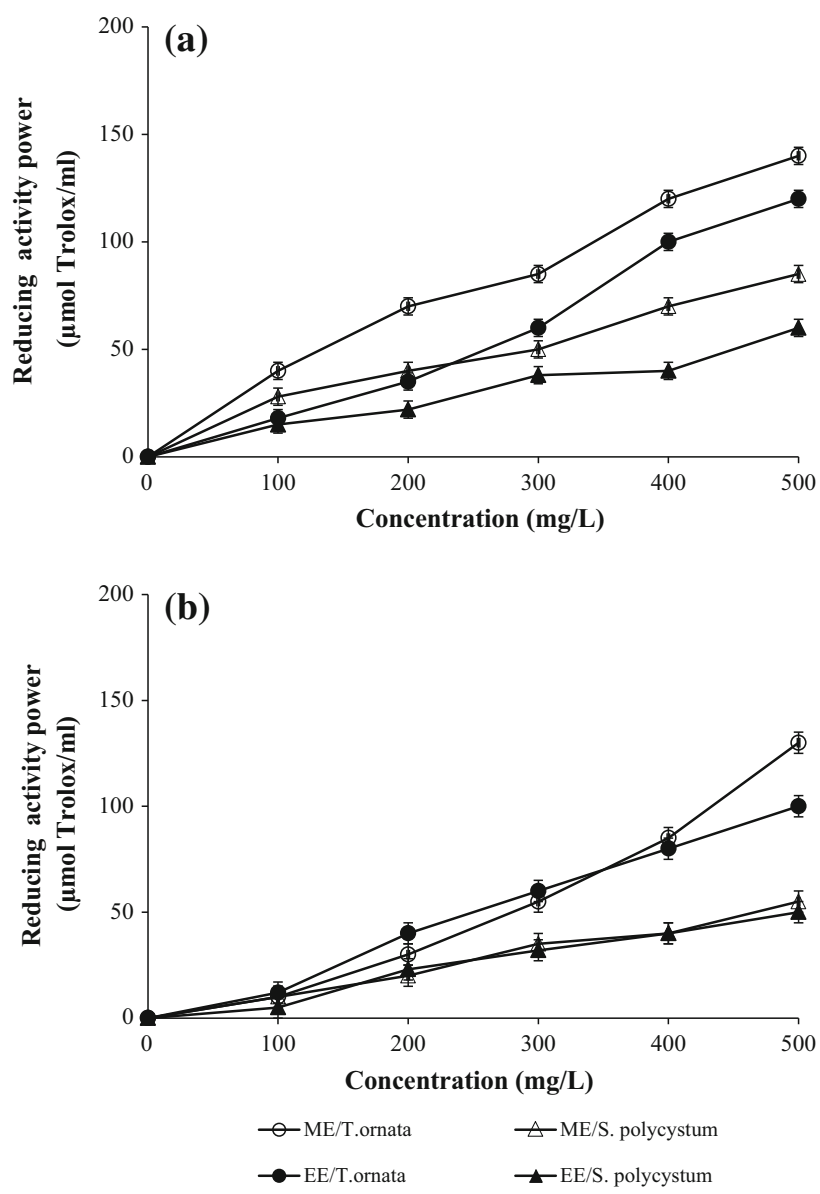

the greater RAP than did those of S. polycystum. For the same extract, RAP was not absolutely in accordance with DPPH and ABTS radical scavenging activities. The result suggested that different extracts contained antioxidative compounds with different functions in inhibiting lipid oxidation. Kuda et al. (2005) and Chandini et al. (2008) reported that methanolic extracts of $T$. conoides and P. tetrastomatica had higher reducing power than did $S$. marginatum. RAP of all extracts increased as the concentrations increased up to $500 \mathrm{mg} / \mathrm{L}(p<0.05)$. RAP indicated that all extracts were capable of donating the electrons to the radicals, in which propagation could be terminated or retarded.

The correlation between antioxidative activities tested by different assays

The correlations between antioxidative activities determined by different assays and reported as Trolox equivalent antioxidant capacity (TEAC) were observed (Fig. 5). Their linear correlations could be described as $\mathrm{TEAC}_{\mathrm{ABTS}}=5.1562 \mathrm{TEAC}_{\mathrm{DPPH}}\left(R^{2}=0.8732\right), \quad \mathrm{TEAC}_{\mathrm{RAP}}=0.7186 \mathrm{TEAC}_{\mathrm{ABTS}}\left(R^{2}=0.7178\right)$, and TEAC $_{\text {RAP }}=3.8178 \mathrm{TEAC} \mathrm{DPPH}_{\mathrm{DP}}\left(R^{2}=0.7150\right)$. Zhao et al. (2006) also reported the correlation between antioxidative activity of barley extract tested by DPPH and ABTS radical scavenging activities and reducing power ( $R^{2}$ ranging from 0.902 to 0.992 ). Nevertheless, Śanchez et al. (2007) reported the best correlation between total polyphenol contents and antioxidant capacity determined by ABTS and DPPH radical scavenging activity method $\left(R^{2}=0.8927\right.$ and 0.8052 , respectively) in virgin olive oil. The result revealed that brown seaweed extracts possessed the ability in donating electron as well as the capability of scavenging various radicals. It could be inferred that the extracts could be used as antioxidants. Since methanolic extract of $T$. ornata had the highest antioxidative activity determined by all assays, it was used to prevent lipid oxidation in different systems. 
Fig. 5 Correlation between ABTS and DPPH radical scavenging activity (a), RAP and ABTS radical scavenging activity (b) and RAP and DPPH radical scavenging activity (c) of the extract of T. ornata and S. polycystum without and with chlorophyll removal
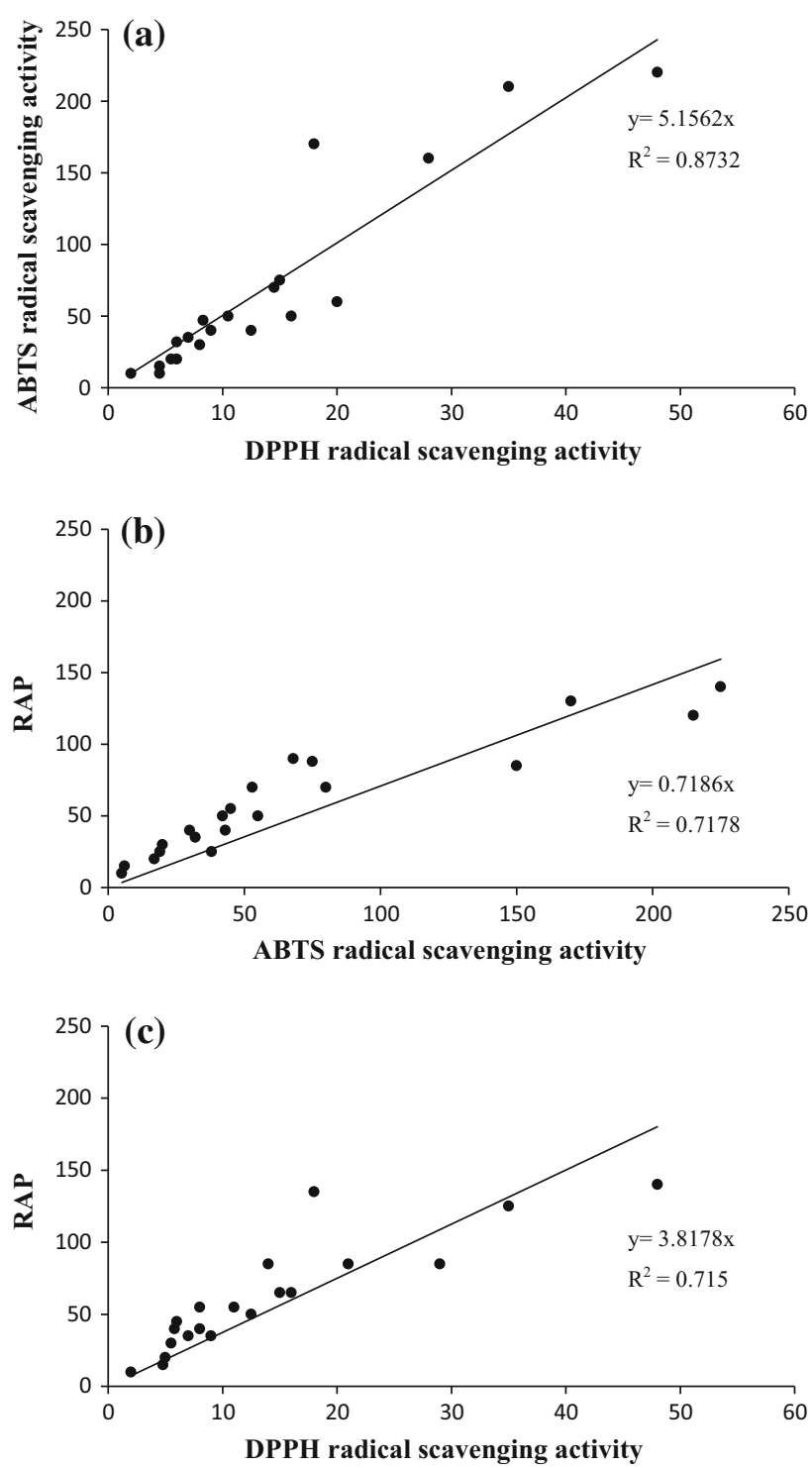

Antioxidative activity of seaweed extract in different systems

\section{Lecithin liposome system}

Antioxidative activities of methanolic extract of $T$. ornata at different concentrations in lecithin liposome system as monitored by the formation of TBARS during incubation at $37{ }^{\circ} \mathrm{C}$ are shown in Fig. 6 . Generally, the increase in liposome oxidation was observed when incubation time increased up to $30 \mathrm{~h}(p<0.05)$. During the first $6-30 \mathrm{~h}$ of incubation, the sharp increases in TBARS were found in the control. Systems containing seaweed methanolic extract had lower TBARS than did the control throughout the incubation of $48 \mathrm{~h}$. TBARS values in liposome system added with 50 , and $200 \mathrm{mg} / \mathrm{L}$ BHT was very low throughout the incubation period of $48 \mathrm{~h}(p<0.05)$. When the methanolic extract without chlorophyll removal was used (Fig. 6a), the liposome system added with 200 ppm extract generally had lower TBARS than did that with $100 \mathrm{ppm}$ extract. However, when the extract was used at $500 \mathrm{ppm}$, the liposome system showed higher TBARS than the others. This was more likely attributable to the pro-oxidative effect of chlorophyll containing in the seaweed extract (Wanasundara and Shahidi 1998). TBARS values represent the content of secondary lipid oxidation products, mainly aldehydes (or carbonyls), that contribute to off-flavors in oxidized oils 
Fig. 6 Changes in TBARS (mg MDA/ml liposome) of lecithin liposome system containing methanolic extract of $T$. ornata without (a) and with (b) chlorophyll removal at different levels. Bars represent the standard deviation from triplicate determinations
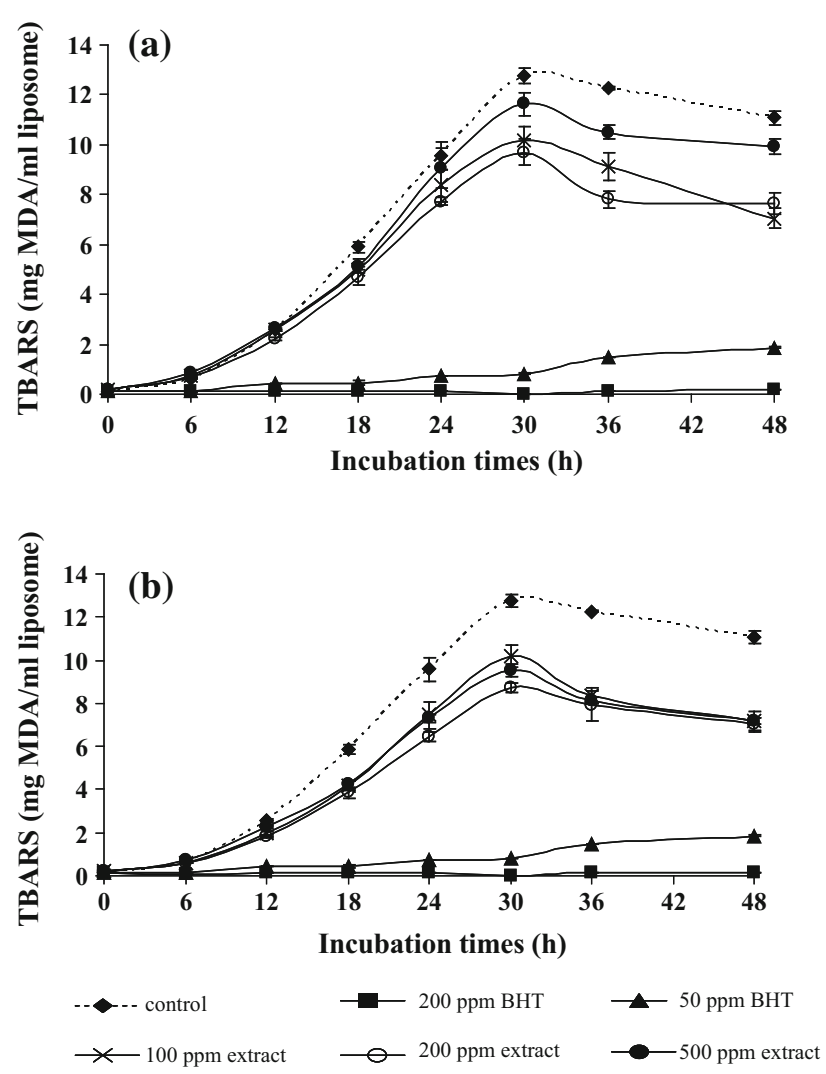

(Wanasundara and Shahidi 1998). The decrease in TBARS was found after $30 \mathrm{~h}$ of incubation. This might be due to the losses in secondary products with low molecular weight, leading to lower amount of such products (Stanhne 1995). The extract with chlorophyll removal exhibited the higher antioxidant activity than did that without chlorophyll removal in this system $(\mathrm{p}<0.05)$. This was probably due to the pro-oxidative effect of chlorophylls and their derivatives in this system. Wanasundara and Shahidi (1998) reported that ethanolic green tea extract (GTE) with chlorophyll showed pro-oxidative activity in seal blubber oil (SBO) and menhaden oil (MHO). However, after dechlorophyllization, the extract exhibited antioxidant activity in both SBO and MHO oil. However, He and Shahidi (1997) found that GTE, despite the presence of chlorophyll, had an antioxidant effect when applied to white muscles of mackerel. Therefore, antioxidant/pro-oxidant activity of GTE was system-dependent (He and Shahidi 1997). The results indicated that methanolic extract of T. ornata could inhibit lipid oxidation, irrespective of chlorophyll removal.

\section{Linoleic oxidation system}

The oxidation of linoleic acid as monitored by the increase in absorbance at $500 \mathrm{~nm}\left(A_{500}\right)$ in systems containing methanolic extract of $T$. ornata at different levels during the incubation at $40{ }^{\circ} \mathrm{C}$ for 10 days is shown in Fig. 7. All samples had a continuous increase in $A_{500}$ throughout 10 days of incubation and the control showed the highest rate of increase. During incubation, for the systems added with the extract without chlorophyll removal (Fig. 7a), no significant difference in $A_{500}$ was found, compared with the control, except after 7 days of incubation, when the lower $A_{500}$ was found in sample added with the extract. For system containing the extract with chlorophyll removal at all concentrations had the lower oxidation as evidenced by lower $A_{500}$, compared with the control $(p<0.05)$ (Fig. 7b). The results showed that after dechlorophyllization the seaweed extract exhibited higher antioxidant activity as evidenced by the lower $A_{500}(p<0.05)$ when compared to the extract without chlorophyll removal. Reaction medium which contains unsaturated fatty acids promotes the decomposition of chlorophyll to release the metal-free, behaving as prooxidant at higher concentrations (Usuki et al. 1984). Santoso et al. (2004) reported that 
Fig. 7 Changes in $A_{500}$ of linoleic acid system containing methanolic extract of $T$. ornata without (a) and with (b) chlorophyll removal at different levels. Bars represent the standard deviation from triplicate determinations
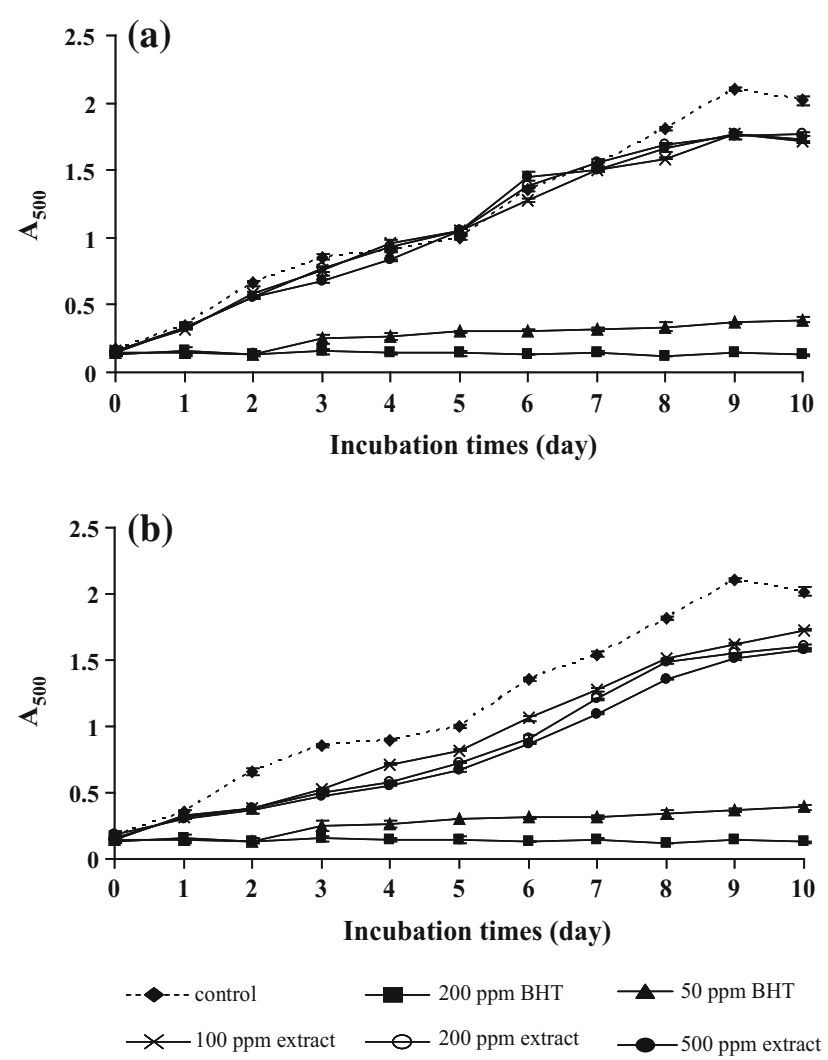

methanolic extract from seaweed contained not only polyphenolic compounds but also other compounds such as polyunsaturated fatty acid (e.g., eicosapentaenoic acid), minerals (e.g., copper, iron), and pigment (e.g., chlorophyll). These components might interact with polyphenolic compounds or affect directly to the emulsion system; therefore, they might act like a pro-oxidant. Linoleic acid is a C18:2 fatty acid with two double bonds at $\mathrm{C} 9$ and $\mathrm{C} 12$ and is one of the major unsaturated fatty acids in vegetable oils. The isomeric structures of hydroperoxides and decomposition volatile compounds from linoleic acid or methyl linoleate by auto-oxidation and photosensitized oxidation have been studied extensively (Frankel 1985). Lipid peroxidation is thought to proceed via radical-mediated abstraction of hydrogen atoms from methylene carbons in polyunsaturated fatty acids (Rajapakse et al. 2005). In food-related systems, anti-oxidant activity is mainly due to the chain-breaking inhibition of lipid peroxidation (Morales and Jimennez-Perez 2001). Therefore, brown seaweed extract could retard lipid oxidation in the emulsion system. However, the efficiency was lower than BHT at both levels $(50$ and $200 \mathrm{mg} / \mathrm{L})$.

Antimicrobial activity of brown seaweed extracts

Methanolic and ethanolic extracts of T. ornata and S. polycystum without and with chlorophyll removal at $500 \mathrm{mg} / \mathrm{L}$ was able to inhibit only gram-positive bacteria (S. aureus) but could not inhibit gram-negative bacteria ( $S$. enteritidis), gram-positive bacteria, spore-forming rods (B. subtilis), and fungi (A. niger) (Table 3). Similar clear zone diameter was observed among all extracts tested, but methanolic extract of $T$. ornata tended to exhibit the highest inhibition against $S$. aureus. Antimicrobial activity of extract could be because phenols reacted primarily with the phospholipids component of cell membrane (Ely et al. 2004). Different active compounds in different brown seaweeds extracts such as spatane diterpenoids, 19-accetoxy-5, 15,18-trihydrxyapata-13,16-diene, from Stoechospermum marginatum (de Silva et al. 1982) methoxybifurcarenone, from Cystoseira tamariscifolia (Bennamara et al. 1999) and phlorotannins, from Ecklonia kurome (Nagayama et al. 2002) were reported. 
Table 3 Inhibition zone of different microorganisms in the presence of methanolic and ethanolic extracts of $T$. ornata and $S$. polycystum with and without chlorophyll removal at $500 \mathrm{mg} / \mathrm{L}$

\begin{tabular}{|c|c|c|c|c|c|}
\hline Seaweeds & Extracts & B. subtilis & S. aureus & S. enteritidis & A. niger \\
\hline \multirow[t]{4}{*}{ T. ornata } & $\mathrm{ME} / \mathrm{W}$ & - & 6.0 & - & - \\
\hline & ME/W/O & - & 6.0 & - & - \\
\hline & EE/W & - & 6.0 & - & - \\
\hline & $\mathrm{EE} / \mathrm{W} / \mathrm{O}$ & - & 6.0 & - & - \\
\hline \multirow[t]{4}{*}{ S. polycystum } & ME/W & - & 7.0 & - & - \\
\hline & $\mathrm{ME} / \mathrm{W} / \mathrm{O}$ & - & 6.0 & - & - \\
\hline & EE/W & - & 6.0 & - & - \\
\hline & EE/W/O & - & 6.5 & - & - \\
\hline
\end{tabular}

The value is the distance $(\mathrm{mm})$ across the zone of inhibition and the disk (diameter $5 \mathrm{~mm}$ )

Values are the mean values of triplicate determinations

- no inhibition; B. subtilis: Bacillus subtilis; S. aureus: Staphylococcus aureus; S. enteritidis: S. enteritidis; A. niger: Aspergillus niger; ME/W: methanolic extract with chlorophyll removal; ME/W/O: methanolic extract without chlorophyll removal; EE/W: ethanolic extract with chlorophyll removal; EE/W/O: ethanolic extract without chlorophyll removal

\section{Conclusion}

Methanolic extracts of brown seaweeds, $T$. ornata and $S$. polycystum, exhibited effectively antioxidative activity. The activity increased with increasing the total phenolic content in the extracts. Antioxidants in seaweed extracts possessed the capability of scavenging the radicals together with reducing power. Therefore, the extracts of those seaweeds could be a source of natural antioxidants, which could retard lipid oxidation in different model systems, regardless of chlorophyll removal. The extracts at proper concentration could inhibit $S$. aureus, but were not able to inhibit the growth of B. subtilis, S. enteritidis, and A. niger.

Acknowledgments This work was supported by Thai government and Prince of Songkla University. The TRF Senior Research scholar program was also acknowledged.

Conflict of interest The authors declare that they have no competing interests.

Author's contributions SB and TP formulated the hypothesis and designed the study. SR conducted the experiments and analysis of data. SR wrote the manuscript with assistance from SB and TP. All authors read and approved the final manuscript.

Open Access This article is distributed under the terms of the Creative Commons Attribution License which permits any use, distribution, and reproduction in any medium, provided the original author(s) and the source are credited.

\section{References}

Abbott IA (1995) Taxonomy of economic seaweeds: reference to some Pacific species, vol V. California Sea Grant College, Uni. Calif. La Jolla, California

Ang JPO (1986) Analysis of the vegetation structure of a Sargassum community in the Philippines. Mar Ecol-Prog Ser 28:9-19 AOAC (2000) Official methods of analysis, 17th edn. Association of Official Chemists, Gaithersberg, Maryland

Arnao MB, Cano A, Acosta M (2001) The hydrophilic and lipophilic contribution to total antioxidant activity. Food Chem 73:239-244

Athukorala Y, Lee KW, Song CB, Ahn CB, Shin TS, Cha YJ, Shahidi F, Jeon YJ (2003) Potential antioxidant activity of marine red alga Grateloupia filicina extracts. J Food Lipids 10:251-265

Aungtonya C, Liao LM (2002) Marine flora (alga and sea grasses) in the reference collection of the Phuket Marine Biology Center, Thailand. Phuket Mar Biol Center Resour 64:65-68

Baydar NG, Ozkan G, Sagdis O (2005) Total phenolic contents and antimicrobial activity of grape (Vistis vinfera L.) extracts. Food Control 15:335-339

Bennamara A, Abourriche A, Berrada M, Charrouf M, Chaib N, Boudouma M, Garneau FX (1999) Methoxybifurcarenone: an antifungal and antibacterial meroditerpenoid from the brown alga Cystoseira tamariscifolia. Phytochemistry 52:37-40

Burtin P (2003) Nutritional value of seaweeds. Electron J Agric Food Chem 2:498-503

Cahyana AH, Shuto Y, Kinoshita Y (1992) Pyropheophytin a as an antioxidative substance from the marine alga, Arame (Eisennia bicyclis). Biosci Biotechnol Biochem 56:1533-1535 
Chandini SK, Ganesan P, Bhaskar N (2008) In vitro antioxidant activities of three selected brown seaweeds of India. Food Chem 107:707-713

Chen CW, Ho CT (1995) Antioxidant properties of polyphenols extracted from green and black tea. J Food Lipid 2:35-46

Chew YL, Lim YY, Omar M, Khoo KS (2008) Antioxidant activity of three edible seaweeds from two areas in South East Asia. LWT-Food Sci Technol 41:1067-1072

de Silva SMS, Gamage SKT, Savitrikumar N, Balasubramanium S (1982) Antibacterial activity of extract from the brown seaweed Stoechospermum marginatum. Phytcochemistry 21:944-945

Ely R, Supriya T, Naik CG (2004) Antimicrobial activity of marine organisms collected off the coast of South East India. J Exper Mar Biol Ecol 309:121-127

Endo Y, Usuki R, Kaneda T (1985) Antioxidant effects of chlorophyll and pheophytin on the auto-oxidation of oils in dark. I: comparison of the inhibitory effects. J Am Oil Chem Soc 62:1375-1378

Frankel EN (1985) Chemistry of auto-oxidation: mechanism, products and flavor significance. In: Min DB, Smouse TH (eds) Flavor chemistry of fats and oils. Champaign, Illinois, pp 1-37

Frankel EN, Huang SW, Aeschbach R, Prior E (1996) Antioxidant activity of a rosemary extract and its constituents, carnosic acid, carnosol, and rosmarinic acid, in bulk oil and oil-in-water emulsion. J Agric Food Chem 44:131-135

GülĢin İ, Sat Gİ, Beydemir ş, Elmastaş M, Küfrevioğlu Öİ (2004) Comparison of antioxidant activity of clove (Eugenia caryophylata thumb) buds and lavender (Lavandula stoechas L.). Food Chem 87:393-400

Hagerman AE, Riedl KM, Jones GA, Sovik KN, Ritchard NT, Hartzfeid PW (1998) High molecular weight plant polyphenolics tannins as biological antioxidants. J Agric Food Chem 46:1887-1892

He Y, Shahidi F (1997) Antioxidant activity of green tea and its catechins in a fish meat model system. J Agric Food Chem 45:4262-4266

Heo SJ, Park EJ, Lee KW, Jeon YJ (2005) Antioxidant activities of enzymatic extracts from brown seaweeds. Biores Technol 96:1613-1623

Kehrer JP (1993) Free radicals as mediators of tissue injury and disease. CRC Crit Rev Toxicol 23:21-48

Koleva II, Linssen JPH, Beek TAV, Evstatieva LN, Kortenska V, Handjieva N (2003) Antioxidant activity screening of extracts from Sideritis species (Labiatae) grown in Bulgaria. J Sci Food Agric 83:809-819

Kranl K, Schlesier K, Bitsch R, Hermann H, Rohe M, Böhm V (2005) Comparing antioxidative food additives and secondary plant products use of different assays. Am J Clin Nutr 93:171-175

Kuda T, Tsunekawa M, Goto H, Araki Y (2005) Antioxidant properties of four edible algae harvested in the Noto Peninsuka, Japan. J Food Comp Anal 96:625-633

Kumaron A, Karunakaran RJ (2007) In vitro antioxidant properties of methanol extract of five Phollanthus species from India. LWT-Food Sci Technol 40:344-352

Lanfer-Marquez UM, Barros RMC, Sinnecker P (2005) Antioxidant activity of chlorophylls and their derivatives. Food Res Int 38:885-891

Leong LP, Shui G (2002) An investigation of antioxidant capacity of fruits in Singapore markets. Food Chem 76:69-75

Lewmanomont K (1995) Algae in Thailand. Office of Environmental Policy and Planning, Ministry of Science, Technology and Environment, Bangkok

Lim SN, Cheung PCK, Ooi VEC, Ang PO (2002) Evaluation of antioxidative activity of extracts from a brown seaweed Sargassum siliquastrum. Food Chem 50:3862-3866

Mayakun J, Prathep A (2005) Seasonal variations in diversity and abundance of macroalgae at Samui Island, Surat Thani Province, Thailand. Songklanakarin J Sci Technol 27(Suppl 3):653-663

Morales FJ, Jimennez-Perez S (2001) Free radical scavenging capacity of Maillard reaction products as related to color and fluorescence. Food Chem 72:119-125

Nagayama K, Iwamura Y, Shibata T, Hirayama I, Nakamura T (2002) Bacteriocidal activity of phlorotannins from the brown alga Ecklonia kurome. J Antimicrob Chemother 50:889-893

Newman DJ, Cragg GM, Snader KM (2003) Natural products as source of new drugs over the period 1981-2002. J Nat Prod 66:1022-1037

Prathep A (2005) Spatial and temporal variations in diversity and percentage cover of macroalgae at Sirinart Marine National Park, Phuket province, Thailand. Sci Asia 31:225-233

Rajapakse N, Mendis E, Jung WK, Je JY, Kim SK (2005) Purification of a radical scavenging peptide from fermented mussel sauce and its antioxidant properties. Food Res Int 38:175-182

Sakanaka S, Tachibana Y, Ishihara N, Juneja LR (2004) Antioxidant activity of egg-yolk protein hydrolysates in a linoleic acid oxidation system. Food Chem 86:99-103

Śanchez CS, Gonźalez AMT, Garćı-Parrilla MC, Granados JJQ, Garćı de la Serrana HL, Martınez MCL (2007) Different radical scavenging tests in virgin olive oil and their relation to the total phenol content. Anal Chem Acta 593:103-107

Santoso J, Yoshie-Stark Y, Suzuki T (2004) Anti-oxidant activity of methanol extracts from Indonesian seaweeds in an oil emulsion model. Fish Sci 70:183-188

Siriwardhana N, Lee KW, Kim SH, Ha JW, Jeon YJ (2003) Antioxidant activity of Hizikia fusiformis on reactive oxygen species scavenging and lipid peroxidation inhibition. Food Sci Technol Int 9:339-346

Slinkard K, Singleton VL (1997) Total phenol analyses: automation and comparison with manual methods. Am J EcolVittic 28:49-55

Smith JE, Hunter CL, Smith CM (2002) Distribution and reproductive characteristics of nonindigenous and invasive marine algae in the Hawaiian Islands. Pac Sci 56:299-315

Stanhne LH (1995) Dried sausages fermented with Staphylococcus pylorus at different temperatures and different ingredient levels- part II volatile components. Meat Sci 41:193-209 
Terada S, Maeda Y, Masui T, Suzuki Y, Ina K (1987) Comparison of caffenine and catechin components in infusion of various tea and tea drinks. Nippon Shokuhin Kogyo Gakkaishi Japan 34:20-27

Usuki R, Suzuki T, Endo Y, Kaneda TK (1984) Residual amounts of chlorophylls and pheophytins in refined edible oils. J Biol Chem 48:991-994

Wanasundara UN, Shahidi F (1998) Antioxidant and pro-oxidant activity of green tea extracts in marine oils. Food Chem 63:335-342

Wong DWS (1989) Mechanism and theory in food chemistry. Van Nostrand Reinhold, New York

Wu HC, Chen HM, Shiau CY (2003) Free amino acids and peptides as related to antioxidant properties in protein hydrolysates of mackerel (Scomber austriasicus). Food Res Int 36:949-957

Yamaguchi T, Takamura H, Matoba T, Teara J (1998) HPLC method for evaluation of the free radical-scavenging activity of food by using 1,1-diphenyl-2-picrylhydrazyl. Biosci Biotechnol Biochem 62:1201-1204

Yan X, Nagata T, Fan X (1999) Antioxidative activities in some common seaweeds. Plant Foods Hum Nutr 52:253-262

Yangthong M, Hutadilok-Towatan N, Phromkunthong W (2009) Antioxidant activities of four edible seaweeds from the southern coast of Thailand. Plant Foods Hum Nutr 64:218-223

Yoshie Y, Wang W, Petillo D, Suzuki T (2000) Distribution of catechins in Japanese seaweeds. Fish Sci 66:998-1000

Zhao H, Dong J, Lu J, Chen J, Li Y, Shan L, Line Y, Fan W, Gu G (2006) Effects of extraction solvent mixtures on antioxidant activity evaluation and their extraction capacity and selectivity for free phenolic compounds in barley (Hordeum vulgare L.). J Agric Food Chem 54:7277-7286 